\title{
Teachers' Attitude towards Teaching of Sexuality Education in Federal Government Colleges in Nigeria - Implications for Counselling
}

\author{
Anna Onoyase ${ }^{1}$ \\ ${ }^{1}$ Department of Guidance and Counselling, Delta State University, P.M.B. 1, Abraka, Delta State, Nigeria \\ Correspondence: Anna Onoyase, Department of Guidance and Counselling, Delta State University, P.M.B. 1, \\ Abraka, Delta State, Nigeria. Tel: 080-3579-9712. E-mail: tinaonoyase@gmail.com
}

Received: September 8, 2018

Accepted: September 21, $2018 \quad$ Online Published: November 14, 2018

doi:10.5539/hes.v8n4p162

URL: https://doi.org/10.5539/hes.v8n4p162

\begin{abstract}
The study investigated the attitude of teachers towards the teaching of sexuality education in federal government colleges in Nigeria. In order to carry out the investigation, three hypotheses were formulated. An instrument known as "teachers' attitude towards teaching of sexuality education" (TATTOSE), was used to obtain information from the respondents. The instrument had a reliability coefficient of 0.79 . It also had language appropriateness, content and facial validity. Four research assistants were used to administer 580 copies of the questionnaire to the respondents. Five hundred and twenty eight copies were retrieved showing 91.03 percent return rate. The data collected from the field were analyzed using t-test statistics. The research found out that there was no significant difference in the attitude of male and female teachers towards the teaching of sexuality education, that there was significant difference in the attitude of less experienced and experienced teachers towards the teaching of sexuality education. Finally, the study also revealed that there was no significant difference in the attitude of married and unmarried teachers towards teaching of sexuality education in Nigeria. One of the recommendations is that a curriculum of sexuality education should be drawn up for secondary schools.
\end{abstract}

Keywords: teachers, attitude, sexuality education

\section{Introduction}

In the Nigerian society, issues of sex and sexuality are hardly ever discussed with children. Parents in most cases, appear to be seriously opposed to passing such information to their children. This is because they believe that such issues might make youths to be morally loosed. But in recent times, as a result of technological advancement especially in the area of Information and Communication Technology (ICT), children have on their own acquired such concealed information from the social media and this seems to have exposed some of the youths to sexual promiscuity. This is because they want to experiment on anything new. There appears to be increase in teenage pregnancy, contacting of sex-related diseases such as gonorrhoea, symphilis, Human Immune Deficiency Virus (HIV), and Acquired Immune Deficiency Syndrome (AIDS). This is where the teaching of sexuality education comes.

Toor (2012) stated that sexuality education is a lifelong process of building a strong foundation for sexual health through acquiring information and forming attitudes, beliefs and values about identity, relationships and intimacy. Toor stressed that sexuality education encompasses education about reproductive health, reproductive rights and responsibilities, sexual abstinence, anatomy of human sex, reproduction and other aspects of human sexual behaviours.

Duntoye, Bukoye and Rasaq (2008: 189) outlined the objectives of sexuality education to include the followings:

- To assist individuals in having a clean and factual view of sexuality.

- To provide individuals with information and skills necessary for rational decision making about their sexual health.

- To change and effect behaviour on sexuality.

- To prevent the occurrence and spread of HIV/ AIDs.

- To enable individuals to have the knowledge of sexuality education at an appropriate age. 
- To help individuals to appreciate their bodies and affirm personal dignity and self-worth; and

- To help individuals interact with both sexes in respectful and responsible manners.

The school is a secondary social unit. The crucial responsibility of the school in the socialization process of the child most especially, the adolescent cannot be over-emphasized. As far as Onoyase (2013: 45) is concerned, the school is an agent of secondary socialization after the home. It is supposed to provide the child with all round education, that is, intellectually, morally, spiritually and physically. Onoyase (2013: 101) believes that many of the secondary school students are adolescents and their behaviours are influenced by their physical development.

The girl, during this stage notices certain physical changes in her body which may be indications that she is matured for sexual activities. It makes her to look for a boyfriend. Onoyase opined that in the case of the boy, the appearance of pubic hair is a sign that he is no longer a boy but a man and he is also interested in having a girlfriend.

It appears that this is the most delicate period in the life of the child because any mistake concerning sexuality education may affect him/ her throughout life. In the views of Eskay, Joachim and Modebelu (2012), Chukwuma, Obiekea and Ovri, (2013), "sexuality or sex education seem to be a no-talk-issue in both schools and homes and that the only channel that is open to adolescents for discussion about sex and sexuality education is their peers, but the information provided by the peers about sexuality education are not always accurate". Esere (2006) stressed that the appropriate place where sexuality can be discussed with adolescents could be in the school because classroom interaction between teachers and students has been found to play important role in the preparation of adolescents for effective personal development and an effective health habits.

Ugoji (2009: 73) has reported that in many countries, concern has been shown about the sexual and reproductive health of adolescents because of the increase in their sexual activity that has also led to an increase in rates of teenage pregnancy and high rates of Human Immune - Deficiency Virus (HIV) among adolescents. Huliyappa (2011) has asserted that there is substantial increase in Sexually Transmitted Disease (STD) and HIV in the past decade and that children who most likely engage in early sexual activity will have learning problems or low academic attainment thus, the need for adolescent sex education and counselling.

Ugoji (2009) investigated the Attitude of Parents towards Sexuality Education in Secondary Schools in Delta State. The purpose of the study was to ascertain parents' attitude towards sexuality education in secondary schools. The population of the study consisted of all parents of secondary school students. The researcher used stratified random sampling technique to sample 600 parents that participated in the study. The investigator used the $\mathrm{Z}$ statistics to test the hypotheses at 0.05 level of significance. The findings showed that there is significant difference in the attitudes of young and old parents towards sexuality education in secondary schools and there is a significant difference in the attitude of parents living in urban and rural areas towards sexuality education in secondary schools. There is no significant difference in the attitude of male and female parents towards sexuality education in secondary schools, but there is significant difference in the attitude of parents based on their level of education towards sexuality education in secondary schools.

Abubakar and Sa'ldu (2014) carried out an investigation of Attitude of Secondary School Teachers Towards Teaching Sexuality Education in Kano State. The objectives of the study were:

i. To determine the attitude of teachers towards teaching sexuality education in secondary schools in Kano State.

ii. To determine whether there is gender difference existing between teachers' attitude towards teaching sexuality education in secondary schools in Kano State; and

iii. To determine whether difference exists between teachers' attitude towards teaching of sexuality education in secondary schools in Kano state based on subject area of teaching.

The population of the study was made up of 868 teachers of senior secondary students. The researcher sampled 643 teachers that participated in the study. The investigator used t-test and ANOVA to test the hypotheses. The findings showed that there was no significant difference between teachers with negative and positive attitude towards teaching sexuality education among secondary school teachers, there is no significant difference between male and female teachers towards teaching sexuality education, there was no significant difference on the attitude towards teaching sexuality education and religious, arts and science teachers in secondary schools.

Eko, Abeshi, Osonwa, Uwanede and Offiong (2013) carried out a study on Perception of Students, Teachers and Parents towards Sexuality Education in Calabar South Local Government Area of Cross River State, Nigeria. The objective of the study according to them "was to determine the perception of students, teachers and parents 
towards sexuality education in Calabar South Local Government Area Cross River State". A total of 850 students, teachers and parents participated in the study. The study found out that the majority of students, teachers and parents were in favour of sexuality education, which should include knowledge of HIV/ AIDs, abstinence and other sexually transmitted diseases.

Dehahani, Nasiriani, Pour, Movahed and Deghani (2015) undertook the study of Teachers' Attitude regarding Sex Education to Adolescents of Secondary and High School Teachers in Yazd South East Iran. The researchers stated that, "the objective of the study was to determine teachers' attitude about sex education to adolescents". 336 secondary and high school teachers participated in the study. The investigators selected the participants in the study using cluster sampling methods. One of the finding showed that teachers were in favour of necessity of sex education as one of the fundamental rights of young adults and stressed that sex education in schools must cover issues regarding maturity, menstruation and abstinence.

Kinley (2015) investigated the Attitude of Teachers and Students Towards Teaching of Sex Education among Secondary Schools in Thimphu Bhutan, Asia. The objective of the study according to the researcher, was to study the attitude of teachers and students towards inclusion of sex education in school curriculum. A total of 120 respondents participated in the study. The finding shows that teachers and students alike were in favour of teaching sex education in secondary schools.

Iwu, Onoja, Ijioma, Ngumah and Egeruoh (2011) undertook the study of "Integration of Sexuality Education in Secondary Biology curriculum for Sustainable Development: "Teachers perception". The investigators stated that, "the purpose of their research was to find out the perception of teachers on the integration of sexuality education in secondary school Biology curriculum in Imo State Nigeria". 102 teachers took part in the study and the finding, showed that majority of the teachers were in favour of teaching sexuality education.

\section{Statement of the Problem}

Adolescence is a stage when youths begin to learn so much about themselves and try to adjust to emerging changes in their anatomy. This stage corresponds with the fifth stage of Erik Erikson's theory of personality development titled "Identity versus Role confusion". During this period, the adolescent is expected to perform some developmental tasks (such as attaining matured relationships with peers, of the same and opposite sex, choosing a career and preparing for it and maintaining emotional maturity) and sometimes becomes confused about these expectations when he is unable to attain them. The physical changes manifested in the adolescent at this stage are accompanied with new sexual feelings for which they need some clarifications.

Incidentally; parents who are expected to provide the necessary emotional support are unable to, because of their beliefs that discussing sexual issues with children may negate cultural practices in Nigeria specifically and Africa in general. Therefore, these youths resort to their peers and social media for such information which may sometimes be misleading and have grave consequences. Thus, the need to include sexuality education in the curriculum of Federal Government Colleges cannot be overemphasized. The topic put in a question form is: What is the attitude of teachers towards the teaching of sexuality education in Federal Government Colleges in Nigeria?

\subsection{Hypotheses}

Three hypotheses were formulated to guide the study:

1. There is no significant difference in the attitude of male and female teachers towards the teaching of sexuality education in Federal Government Colleges in Nigeria.

2. There is no significant difference in the attitude of experienced and less experienced teachers towards the teaching of sexuality education in Federal Government Colleges in Nigeria.

3. There is no significant difference in the attitude of married and unmarried teachers towards the teaching of sexuality education in Federal Government Colleges in Nigeria

\subsection{Operational Definition of Terms}

Sexuality education revolves around the information provided to adolescents so as to understand their anatomy and make responsible choices about their sexual relations.

\subsection{Research Procedure and Methodology}

This study is a descriptive research. Egbule and Okobia (2012: 24) have asserted that descriptive survey systematically describes a situation or an area of interest factually and accurately by employing: a public opinion survey, observation, interviews or through sample questionnaires. They stressed that, sometimes, descriptive 
research can be referred to as "status study or fact finding survey".

The population of the study was made up of all teachers in the 104 Federal Government colleges in Nigeria. The researcher used the random sampling method to select $30 \%$ of the schools used. The investigator then used purposive sampling technique to sample 580 teachers who took part in the study. The researcher made use of an instrument known as "Teachers' Attitude towards Teaching of Sexuality Education" (TATTOSE) to obtain information from the respondents. The instrument was made up of a 4 point rating scale of strongly Agree (SA) 4 points, Agree (A), 3 points, Disagree (DA), 2 points and Strongly Disagree (SD), 1 point. It had a reliability coefficient of 0.79 , language appropriateness, content and facial validity. Four research assistants were used to administer 580 copies of the questionnaire to the respondents. Five hundred and twenty eight copies of the questionnaire were retrieved showing 91.03 percent return rate.

The data collected from the field work were collated and the t-test statistics was used to test the hypotheses at 0.05 level of significance.

\section{Findings}

\subsection{Hypothesis One}

There is no significant difference in the attitude of male and female teachers towards the teaching of sexuality education in federal government colleges in Nigeria.

Table 1. T-test analysis on the attitude of male and female teachers towards the teaching of sexuality education in federal government colleges in Nigeria

\begin{tabular}{lllllllll}
\hline Variables & $\mathrm{N}$ & Mean & SD & DF & t-cal & t-crit & Level of sign. & Decision \\
\hline Male teachers & 226 & 48.73 & 4.82 & 526 & -0.613 & 1.96 & 0.05 & Not sig. Accepted \\
Female teachers & 302 & 49.01 & 5.59 & & & & & \\
\hline
\end{tabular}

Table one shows the calculated t-value to be -0.613 while critical t-value is 1.96 . Since critical t-value of 1.96 is higher than the calculated $t$-value of -0.613 at 0.05 level of significance, the hypothesis which says that there is no significant difference in the attitude of male and female teachers towards the teaching of sexuality education is accepted. The finding has shown that whether the teacher is a male or female does not matter, all of them have accepted the teaching of sexuality education.

\subsection{Hypothesis Two}

There is no significant difference in the attitude of less experienced and experienced teachers towards the teaching of sexuality education in Federal Government colleges in Nigeria.

Table 2. T-test Analysis on the Attitude of less Experienced and Experienced Teachers towards the teaching of sexuality education in Federal Government colleges in Nigeria

\begin{tabular}{llllllllc}
\hline Variables & $\mathrm{N}$ & Mean & SD & DF & t-cal & t-crit & Level of sign. & Decision \\
\hline Less experienced teacher & 272 & 49.55 & 5.55 & 526 & 2.985 & 1.96 & 0.05 & Not sig. \\
Experienced teachers & 256 & 48.19 & 4.87 & & & & & Accepted \\
\hline
\end{tabular}

In table two, the calculated t-value is 2.985 while critical t-value is 1.96 . The calculated t-value of 2.985 is greater than the critical t-value of 1.96 at 0.05 level of significance, therefore, the hypothesis which says that there is no significant difference in the attitude of less experienced and experienced teachers towards the teaching of sexuality education is rejected. The level of experience among the teachers may have influenced the attitude that they have expressed towards the teaching of sexuality education. The lack of uniformity in the attitude the teachers have may be due to their experience.

\subsection{Hypothesis three}

There is no significant difference in the attitude of married and unmarried teachers towards the teaching of sexuality education in federal government colleges in Nigeria.

Table 3. T-test Analysis on the attitude of Married and Unmarried Teachers towards the Teaching of sexuality Education in Federal Government colleges in Nigeria

\begin{tabular}{lllllllll}
\hline Variables & $\mathrm{N}$ & Mean & SD & DF & t-cal & t-crit & Level of sign. & Decision \\
\hline Married teachers & 421 & 48.51 & 5.06 & 526 & -3.274 & 1.96 & 0.05 & Not sig. Accepted \\
Unmarried teachers & 107 & 50.36 & 5.82 & & & & & \\
\hline
\end{tabular}


Table 3, revealed that the calculated $t$-value is -3.274 while critical $t$-value is 1.96 . Since the calculated $t$-value of -3.274 is less than the critical t-value of 1.96 at 0.05 level of significance, the hypothesis which says that there is no significant difference in the attitude of married and unmarried teachers towards the teaching of sexuality education is accepted. The finding has shown that the marital status of the teachers was not an issue in the expression of their uniform attitude towards the teaching of sexuality education.

\section{Discussion}

One of the findings of this study is that there is no significant difference in the attitude of male and female teachers towards the teaching of sexuality education in Federal government colleges. The reason one may adduce for the sameness in the attitude of both sexes of teachers is that all of them work in the same environment, have observed that students experience a lot of changes during adolescence and thus manifest behaviours that are anti-social and inimical to their general wellbeing.

This finding lends credence to that of Ugoji (2009) where she found out that there was no significant difference in the attitude of male and female parents towards teaching of sexuality education in Delta State. This present finding equally supports that of Abubakar and Sa'ldu (2014) which revealed that there was no significant difference between male and female teachers towards teaching sexuality education in secondary schools of Kano State.

The second finding of the present study showed that there was significant difference in the attitude of less experienced and experienced teachers towards the teaching of sexuality education. The difference observed in the attitude of less experienced and experienced teachers towards the teaching of sexuality education may be due to the fact that some of the teachers have spent many years in the school and have become conversant with the patterns of adolescents' behaviour, their worries about their looks, their desires to experiment on new things and therefore see the need to furnish them with useful information for healthy development. This finding supports that of Ugoji (2009) when she found out that there was significant difference in the attitude of parents towards teaching of sexuality education in secondary schools based on their level of education.

Finally, the present study found out that there was no significant difference in the attitudes of married and unmarried teachers towards the teaching of sexuality education. The finding gives credence to that of Eko, Abeshi, Osonwa, Uwanede and Offiong (2013) which revealed that majority of teachers, parents, and students were in favour of teaching sexuality education in secondary schools. This investigation also supports the finding of Kinley (2015) which indicated that teachers and students were in favour of teaching sexuality education in secondary schools. This finding equally corroborates that of Dehghani, Nasirioni, Pour, (2015) which revealed that the teachers were in favour of necessity of sex education as one of the fundamental rights of young adults and stressed that sex education in schools must cover issues of maturity, menstruation and abstinence.

\section{Conclusion}

One can therefore conclude that a good number of teachers in Federal Government colleges in Nigeria are favourably disposed to the teaching of sexuality education in secondary schools.

\section{Recommendations}

Based on the findings, the following recommendations are proposed:

1. A curriculum of sexuality education should be drawn up for all secondary schools in Nigeria.

2. The government should train teachers specially to handle sexuality education in schools.

3. Public awareness campaigns should be organised by the government (at all levels) to sensitize members of the public (teachers inclusive) on the need for sexuality education, so that they can be receptive to it.

4. Religious leaders, through their various programmes in churches and mosques should enlighten their members especially the adults (including teachers) about the importance of sexuality education for adolescents in schools.

5. Non-governmental organizations should endeavour to meet with traditional rulers in various communities and emphasize on what adolescents stand to gain from sexuality education so that they can educate their subjects (including teachers) to embrace it.

\section{Counselling Implications}

The following are the implications of this study: 
1. Counsellors should organize parents' conferences and use such media to enumerate to parents (who are teachers) the advantages of teaching sexuality education to students in secondary schools and thus debunk their erroneous beliefs.

2. Counsellors are to organize seminars for teachers on regular basis and stress on what students stand to benefit from the teaching of sexuality education in schools and also to stem the tide of immorality among adolescents.

3. There is need for the Counselling Association of Nigeria (CASSON) at the various State Chapters to liaise with traditional rulers to educate them on the importance of introducing sexuality education in secondary schools and what individuals, corporate organisations and the society at large will gain.

\section{References}

Abubakar, H. S., \& Sa'ldu, G. (2014). Attitude of secondary teachers towards teaching sexuality education in Kano State: Implications for counselling. Perspectives in guidance and counselling Edited by Adegoke A. A. And Aluede O., Benin City: Justice Jeco Printing and Publishing Global.

Chukwuma, E. T. C., Obiekea, P. O., \& Ovri, F. R. (2013). Sexuality Education and intervention and social adjustment programme for youths in secondary education in Nigeria. 7(1) Art 22 Obieken Ovri and Chukwuma pdf. Retrieved from https://afrnevjonet/journalsmultidiscipline.

Dehghani, L., Nasiani, K., Pour Movahed, A., \& Dehghani, H. (2005). Teachers attitude regarding sex education to adolescents. International Journal of Psychology and Behavioural Research, 4(1).

Duntoye, J. A., Bakaye, R. O., \& Rasaq, A. O. (2008). Introduction to Guidance and Counselling Organisation and Practice, Ilorin: Integrity Publications.

Egbule, J. F., \& Okobia, D. O. (2012). Research Methods in Education for Colleges and Universities KMEN5UD, educational Publishers: Onitsha/ 53 Prof. Ebie Street Agbor.

Eko, J. E., Abeshi, S. E., Osanwa, K. O., Advanide, C. C., \& Effiong, D. A. (2013). Perception of students, teachers and parents towards sexuality education in Calabar South Local Government Area Cross River State, Nigeria. Journal of Sociological Research, 4(2). https://doi.org/10.5296/jsr.v4i2.3836

Esere, M. O. (2006). HIV/AIDS Awareness of, in school adolescents in Nigeria, Implications for adolescence sexuality, Journal of Psychology in Africa. 16(2), 255-258. https://doi.org/10.1080/14330237.2006.10820129

Eskay, M., Joachim, C. O., \& Modebelu, J. O. (2010). Roles of counsellors in promoting sexuality education for In-school adolescents in Nigeria. Psychology Research, 2(12), 711-718.

Huliyappa, M. (2011). Sexual counselling in adolescent. Retrieved from http://wnwslideshare.net/manjunathuliyappa

Iwu, R. U., Onoja, A. J., Ijioma, B. C., Ngumah, M. O., \& Egeruoh, A. S. (2011). The integration of sexuality education in secondary school Biology curriculum for sustainable development: Teachers perception. International Journal of Science and Technology Education Research, 2(4).

Kinley, P. (2015). Attitude of teachers and students towards teaching of sex education among secondary schools in Thimphu Bhutan Asia. Unpublished Post-graduate Diploma Research, Royal Institute of Management, Semtokha.

Nwakwo, S. O. (2014). Adolescent sexuality, Needs and counselling services in Senior Secondary School (SSS) in Kwali Abuja. Perspectives in Guidance and counselling, Edited Adegoke, A. A. and Aluede O., Benin City: Justice Jero Printing and Publishing Global.

Onoyase, D. (2013). Sociology of Education, Warri: Johny and Co.

Toor, K. K. (2012). A Study of the attitude of teachers, parents and adolescents towards sexuality education MIER Journal of Educational Studies, 2(2), 177-189.

Ugoji, F. A. (2009). The attitude of parents towards sexuality education in secondary school in Delta State. The counsellor, 26(2), 71-83.

\section{Copyrights}

Copyright for this article is retained by the author(s), with first publication rights granted to the journal.

This is an open-access article distributed under the terms and conditions of the Creative Commons Attribution license (http://creativecommons.org/licenses/by/4.0/). 